\title{
Change of soil mechanical properties due to triaxial sample size
}

\author{
Šarūnas Skuodis ${ }^{1}$, Neringa Dirgèliené ${ }^{2}$, Ieva Lekstutyté ${ }^{3}$ \\ ${ }^{1,2}$ Department of Reinforced Concrete Structures and Geotechnics, Vilnius Gediminas Technical University, \\ Vilnius, Lithuania \\ ${ }^{3}$ Department of Hydrogeology and Engineering Geology, Vilnius University, Vilnius, Lithuania \\ E-mail: ${ }^{2}$ Neringa.Dirgeliene@vgtu.lt (corresponding author)
}

\begin{abstract}
Triaxial test is widely used to determine the behaviour and strength parameters of soil. Several consolidated drained triaxial compression tests were performed on two specimen sizes of sand and clay. This article investigate and compares the influence of specimen size and scale effect on the soil shear strength. The tests results show that the shear strength parameters are influenced by the clay specimen size. The results indicate that the effect of triaxial clay sample size is more significant with higher confining pressures. The second type of tests carried out on sand samples shows that sample size doesn't influence the results of the shear strength. Author's show that clay analyses can be significantly affected by the choice of the specimen size used to determine shear strength parameters.
\end{abstract}

Keywords: triaxial test, effect of specimen size, shear strength, angle of internal friction, cohesion.

\section{Introduction}

Triaxial tests are often used to determine the behavior and strength characteristics of soils (Omar \& Sadrekarimi, 2015). The results of triaxial tests can be influenced by various experimental conditions such as confining pressure, shearing rate, end constraint, and specimen size (Park \& Jeong, 2015). In this study the effect of specimen size on the drained shearing behavior of dense sand and dense clay was investigated using specimens 5 and $10 \mathrm{~cm}$ in diameter. Specimen size can have a significant impact on the measured shear strength (Hu, Dano, Hicher, Le Touzo, \& Derkx, 2011; Cerato \& Lutenegger, 2006). Literature analysis shows the difference between an effective friction angle from undrained tests and drained tests was up to $7^{\circ}$ for loose sand, but was negligible for dense sand using different specimens sizes. There the effect of specimen size on the undrained and drained shearing behavior of Nakdong River sand was investigated using loose and dense specimens 5 and $10 \mathrm{~cm}$ in diameter (Park \& Jeong, 2015). The higher compressibility of smaller specimens during isotropic compression and drained shearing could be due to the larger volumetric fraction of the sand particles near the specimen's sides (Omar \& Sadrekarimi, 2015).

The literature analysis shows that for the same clayey silt sample size, as the over-consolidation ratio increases, the deviator stress increases. This behavior is more significant on the samples which had been initially consolidated at smaller consolidation pressure. The results indicate that the effect of sample size is more significant at higher confining pressures. It was found that the total and effective peak friction angles decreases with increasing sample size (Sivadass, Lee, \& Karim, 2013).

A small diameter sample may not truly represent the "fabric" and "structure" of the soils at the site (Chew \& Bharati, 2011). Testing biger samples sizes gives better representation of field shear and deformation behaviour, so buildings are safer. The reason for different results for larger and smaller is mainly due to the presence of non-uniformity and non-homogeneity in the field which can be captured in large size sample but not in small size sample. Furthermore, the small diameter sample is affected to more sample disturbance during sampling, transportation and sample testing.

The undrained shear strength of marine clay obtained from large diameter triaxial sample is lower than that obtained from small diameter sample, although both samples are obtained from large diameter sampler. The triaxial tests results shows that larger sample size results are $20-70 \%$ lower than that of conventional sample size results (Chew \& Bharati, 2011).

Many laboratories perform triaxial tests on sand or clay to determine the shearing strength of the soil sample. However, there are different size triaxial cells in use today (D. Li, C. C. Li, \& X. Li, 2011; Kuwano \& Mulmi, 2008) and the effect of the varying specimen size (Amšiejus, Dirgèlienè, Norkus, \& Žilionienè, 2009) and soil type (sand or 
over consolidated moraine clay) on the resulting friction angle used in foundation design has never before been investigated in Lithuania thoroughly. The main reason of such a tests lack - very difficult to provide triaxial tests with over consolidated moraine clay. During these experiments it can appear problems with saturation (Kadkhodaie \& Rezaee, 2016; Dong, Kong, \& Zhe, 2016; Glover, 2017), big particles appearance in shearing plane (Zhang, Baudet, Hu, \& Xu, 2017; Vangla \& Latha, 2015), long term investigations (Suzuki, Dyvik, \& Schmertmann, 2017; Liu, Xie, Shao, \& Conil, 2018) and etc. Specimen size effect on the shear strength parameters can affect the design and analysis of many geotechnical constructions. The optimum design of foundations involves a better understanding of the behaviour of the used materials in order to guarantee the safety of its structural behaviour during its lifetime. Soil strength parameters and using them determined soil bearing resistance usually are defined with some errors. If we know the reasons of errors, shortcomings of testing apparatus could be eliminated, method of data evaluation could be developed, soil parameters could be determined more precisely and foundation designed more economically.

This paper presents the shearing strength results of experimental triaxial tests on sand and over consolidated moraine clay samples with different diameters and heights. In this study the effect of specimen size on the drained shearing behavior of dense sand and dense clay was investigated using specimens 5 and $10 \mathrm{~cm}$ in diameter.

\section{Experimental analysis}

\section{Identification of tested soil}

This research work analysing clay, which belongs to the glacial formations of the Middle Pleistocene Medininkai glacial period (gt II md) laying in the eastern part of Lithuanian territory (Lekstutytè, Gadeikis, Žaržojus, \& Skuodis, 2018). An other soil type - sand, which deposited on the Lithuanian coast of the Baltic Sea have been formed during the Quaternary (Skuodis, Markauskas, Norkus, Žaržojus, \& Dirgėlienè, 2014). The investigated area of sand is located in the southern part of the Lithuanian mainland area of the Baltic Sea. Lithuanian standard sand for scientific testing can be Baltic Sea Klaipeda sand, due to granulometry composition and particles shape (Skuodis, Karaman, \& Dirgèliené, 2017). This is the reason, why Klaipéda sand was chosen for investigations as standard soil, according to which results it is provided comparison of over consolidated moraine clay triaxial tests results.

In the triaxial experiments clay and sand were tested in this work. First type of soil according to granulometric curve is sandy silty clay (see Figure 1). The properties of prepared samples are as follows: density $\rho=2.28-2.30 \mathrm{~g} / \mathrm{cm}^{3}$, particles density $\rho_{\mathrm{s}}=2.72 \mathrm{~g} / \mathrm{cm}^{3}$, void ratio $\mathrm{e}=0.29-0.31$, moisture $\mathrm{W}=9-10 \%$, Atterberg liquid limit $\mathrm{W}_{\mathrm{L}}=0.245$, Atterberg plastic limit $\mathrm{W}_{\mathrm{P}}=0.139$, plasticity index $\mathrm{I}_{\mathrm{p}}=0.1$, liquidity index $\mathrm{I}_{\mathrm{L}}=-0.215$. The undisturbed samples were taken from borehole of 12.5-13.1 m depth.

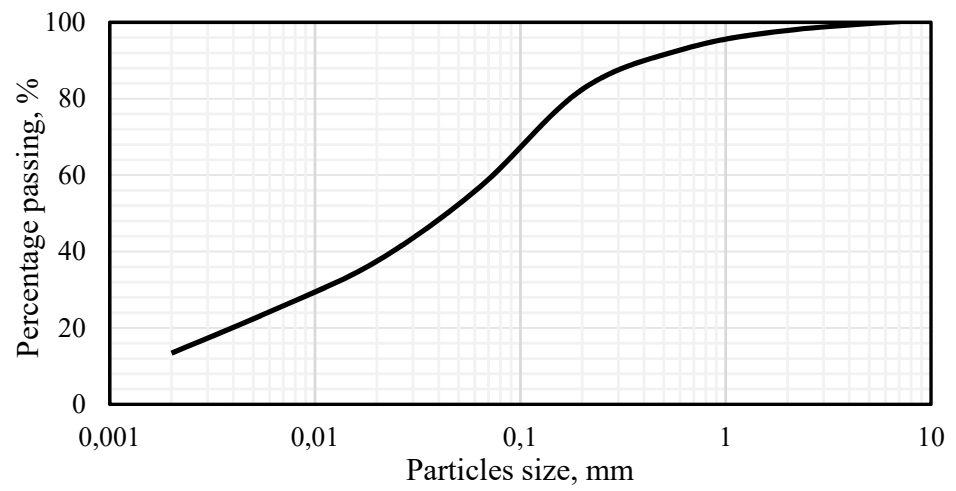

Figure 1. Grain size distribution for clay

The next investigated soil according to granulometric curve is even-graded sand, uniformity coefficient is $\mathrm{C}_{\mathrm{U}}=$ 1.47 and coefficient of curvature is $\mathrm{C}_{\mathrm{C}}=0.93$ (see Figure 2). Soil granulometric composition is of $1.34 \%$ fine, $96.38 \%$ medium and $2.28 \%$ coarse particles, respectively. The particles of this soil are mostly of the same shape, because it is sampled from Klaipeda seashore, where a surface of particles is polished by the waves. The tested sand samples of low water contents $(\mathrm{w}=6 \%)$ have been performed by compacting. The triaxial tests have been performed for samples of density $\rho=1.69 \mathrm{~g} / \mathrm{cm}^{3}$ and the void ratio e $=0.49-0.51$. 


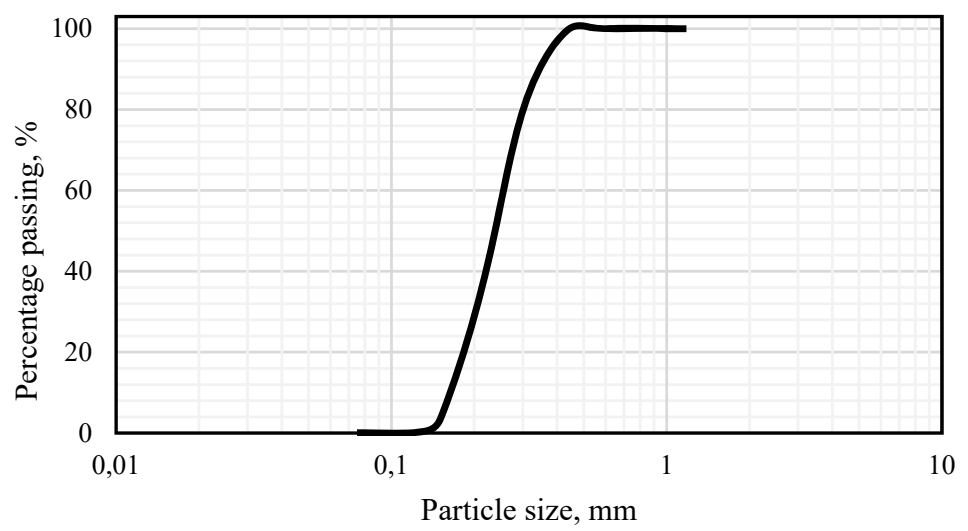

Figure 2. Grain size distribution for sand

\section{Triaxial testing}

The consolidated drained (CD) tests were performed for the specimens of height/diameter ratio of $H / D=2$. For investigation of scale effect the triaxial compression tests were performed on two specimen sizes of sand and clay: first, samples of $50 \mathrm{~mm}$ diameter and $100 \mathrm{~mm}$ height (50/100); second, samples of $100 \mathrm{~mm}$ diameter and $200 \mathrm{~mm}$ height (100/200). The saturation wasn't performed.

Sand compaction was performed in six layers of equal thickness by tamping the top of each layer with a tamper to reach the target density for each specimen.

Each type of the prepared samples has been cut leastwise three times. The tested clay samples have been sheared under three horizontal pressure $\sigma_{3}=150 \mathrm{kPa}, 250 \mathrm{kPa}, 350 \mathrm{kPa}$. The sand samples have been cut under $\sigma_{3}=100 \mathrm{kPa}$, $200 \mathrm{kPa}, 300 \mathrm{kPa}$. An axial strain rate of $0.02 \% / \mathrm{min}$ was used for clay and $0.95 \% / \mathrm{min}$ for sand. Each of the tests was continued up to deformation, which is equal to $15 \%$. The circles representing the state of stress in the traxial samples at failure are drawn (see Figures 3-6).

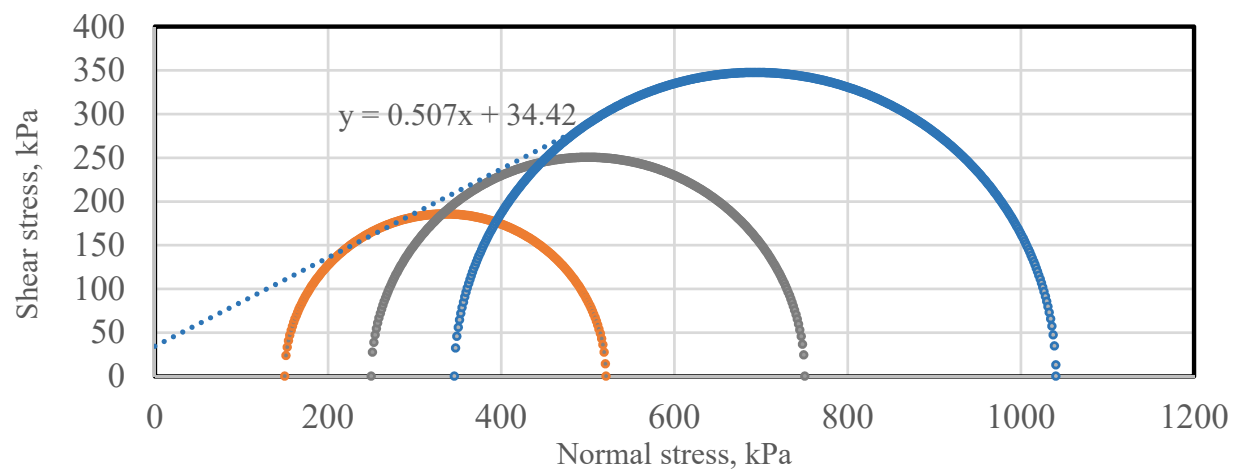

Figure 3. Mohr circles and strength envelope of clay 50/100

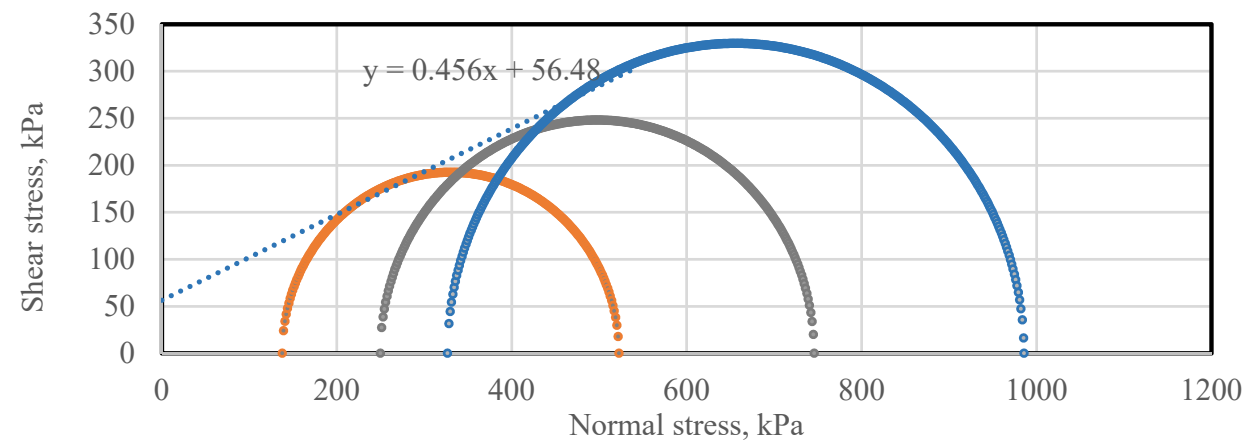

Figure 4. Mohr circles and strength envelope of clay 100/200 


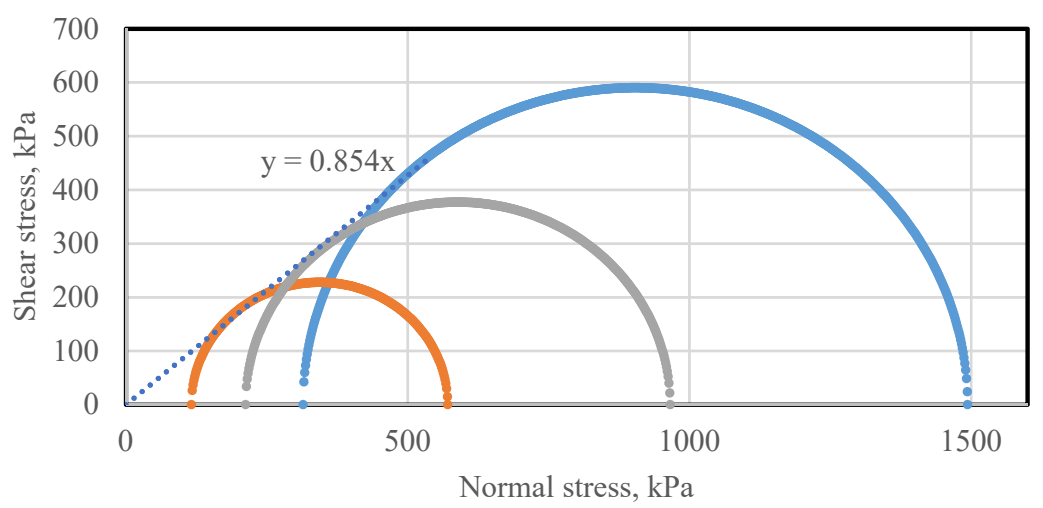

Figure 5. Mohr circles and strength envelope of sand 50/100

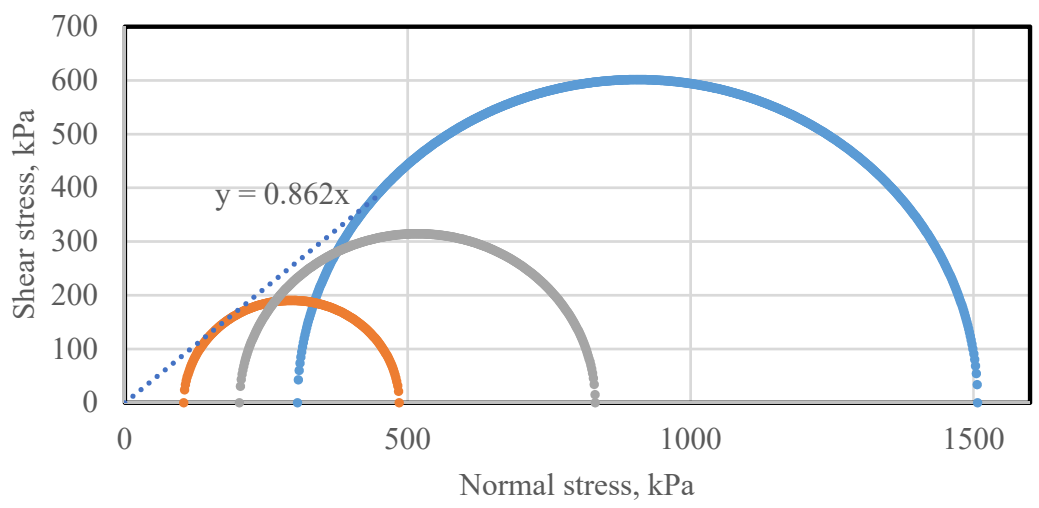

Figure 6. Mohr circles and strength envelope of sand 100/200

\section{Comparison of shear strength}

The first type of tests carried out on over-consolidated moraine clay demonstrates that the angle of peak internal friction in term of effective stress shows variation with sample size. It was determined $\varphi^{\prime}=26.87^{\circ}$ for samples of 50 in diameter and $\varphi^{\prime}=24.50^{\circ}$ for samples of 100 in diameter (Table 1). It was found that the effective peak friction angle decreases with increasing sample size. These results are similar to the results determined by other authors (Sivadass et al., 2013).

From all experiments, it is found that the max deviator stress decreases as the sample size increases. In a drained test the deviator stresses at failure were $371 \mathrm{kPa}, 501 \mathrm{kPa}, 695 \mathrm{kPa}$ for small samples and $384 \mathrm{kPa}, 498 \mathrm{kPa}, 659 \mathrm{kPa}$ for large samples under three horizontal pressure $\sigma_{3}=150 \mathrm{kPa}, 250 \mathrm{kPa}, 350 \mathrm{kPa}$. The maximum deviator stress increases as the confining pressure increases. The results indicate that the effect of triaxial sample size is more significant with higher confining pressures. Whereas effective cohesion shows rise from $34.42 \mathrm{kPa}$ to $56.48 \mathrm{kPa}$ with sample size increment. For clay exhibiting peak stress behavior in the small size samples, axial strain coresponding to peak stress are higher, differing by $\pm 45-100 \%$ from big samples.

Table 1. The peak values of shear strength from triaxial tests

\begin{tabular}{|c|c|c|c|c|}
\hline \multirow{2}{*}{ Type of soil } & \multicolumn{2}{|c|}{ Cohesion c', $\mathrm{kPa}$} & \multicolumn{2}{c|}{ Internal friction angle, $\varphi^{\prime}{ }^{\text {o }}$} \\
\cline { 2 - 5 } & $50 / 100$ & $100 / 200$ & $50 / 100$ & $100 / 200$ \\
\hline clay & 34.42 & 56.48 & 26.87 & 24.50 \\
\hline sand & 0 & 0 & 40.51 & 40.77 \\
\hline
\end{tabular}

The second type of tests carried out on sand samples shows that sample size effect doesn't influence the results of drained triaxial compression tests (Table 1). The cohesion is $\mathrm{c}^{\prime}=0(\mathrm{kPa})$ for both type of samples. The comparison of test data on samples 50 and $100 \mathrm{~mm}$ in diameter, for which the slenderness is the same, does not reveal any difference in the peak angle of internal friction. It was determined $\varphi^{\prime}=40.51^{\circ}$ and $\varphi^{\prime}=40.77^{\circ}$ respectively. Therefore, we can 
conclude that there is no obvious sample size effect in the sand strength behavior. A similar studies on coarse granular materials show comparable results (Hu et al., 2011).

While using small size samples for determining clay shear strength parameters, may result in un-conservative design, the choise of a large sample size is consequently a more accurate representation of soil strength conditions and field deformations.

\section{Conclusions}

1. It was found that the clay effective peak friction angle decreases with increasing sample size from $26.87^{\circ}$ to $24.50^{\circ}$.

2. The results indicate that the effect of triaxial clay sample size is more significant with higher confining pressures.

3. The effective cohesion shows rise from $34.42 \mathrm{kPa}$ to $56.48 \mathrm{kPa}$ with sample size increment.

4. The triaxial experiments does not reveal any difference in the peak angle of internal friction and cohesion of dense sand.

\section{References}

Amšiejus, J., Dirgèlienė, N., Norkus, A., \& Žilionienė, D. (2009). Evaluation of soil shear strength parameters via triaxial testing by height versus diameter ratio of sample. The Baltic Journal of Road and Bridge Engineering, 4(2), 54-60. https://doi.org/10.3846/1822-427X.2009.4.54-60

Cerato, A., \& Luteneger, A. (2006). Specimen size and scale effects of direct shear box tests of sands. Geotechnical Testing Journal, 29(6), 507-516. https://doi.org/10.1520/GTJ100312

Chew, S. H., \& Bharati, S. K. (2011, 2-6 October). Effect of large diameter sample testing for offshore site investigation. In 2011 Pan-Am CGS Geotechnical Conference. Toronto, Ontario, Canada.

Dong, T., Kong, L., \& Zhe, M. (2016). Preparation method and mechanical properties of saturated hollow cylinder specimen of remolded red clay. Electronic Journal of Geotechnical Engineering, 21(20), 6699-6711.

Glover, P. W. J. (2017). A new theoretical interpretation of Archie's saturation exponent. Solid Earth, 8, 805-816. https://doi.org/10.5194/se-8-805-2017

Hu, W., Dano, C., Hicher, P., Le Touzo, J., \& Derkx, F. (2011). Effect of sample size on the behavior of granular materials. Geotechnical Testing Journal, 34(3), 186-197. https://doi.org/10.1520/GTJ103095

Kadkhodaie, A., \& Rezaee, R. (2016). A new correlation for water saturation calculation in gas shale reservoirs based on compensation of kerogen-clay conductivity. Journal of Petroleum Science and Engineering, 146, 932-939. https://doi.org/10.1016/j.petrol.2016.08.004

Kuwano, R., \& Mulmi, S. (2008). Effects of diameter and height of triaxial cylindrical specimen on bender element test. SEISAN KENKYU, 60(3), 225-227. https://doi.org/10.11188/seisankenkyu.60.225

Lekstutyte, I., Gadeikis, S., Žaržojus, G., \& Skuodis, Š. (2018, 11-14 September). Some mechanical properties of Medininkai glacial period overconsolidated moraine clay. In $26^{\text {th }}$ European Young Geotechnical Engineers Conference (pp. 83-92). Reinischkogel, Austria.

Li, D., Li, C. C., \& Li, X. (2011). Influence of sample height-to-width ratios on failure mode for rectangular prism samples of hard rock loaded in uniaxial compression. Rock Mechanics and Rock Engineering, 44(3), 253-267. https://doi.org/10.1007/s00603-010-0127-0

Liu, Z. B., Xie, S. Y., Shao, J. F., \& Conil, N. (2018). Multi-step triaxial compressive creep behaviour and induced gas permeability change of clay-rich rock. Géotechnique, 68(4), 281-289. https://doi.org/10.1680/jgeot.16.P.117

Omar, T., \& Sadrekarimi, A. (2015). Effect of triaxial specimen size on engineering design and analysis. International Journal of Geo-Engineering, 6(5), 1-17. https://doi.org/10.1186/s40703-015-0006-3

Park, S. S., \& Jeong, S. W. (2015). Effect of specimen size on undrained and drained shear strength of sand. Journal Marine Georesources \& Geotechnology, 33(4), 361-366. https://doi.org/10.1080/1064119X.2013.879627

Sivadass, T., Lee, C. Y., \& Karim, M. S. A. (2003, 22-24 September). Behaviour of a tropical residual soil. In Proceedings of the Third International Symposium on Deformation Characteristics of Geomaterials. Lyon, France. https://doi.org/10.1201/NOE9058096043.ch16

Skuodis, Š., Karaman, A. H., \& Dirgèlienė, N. (2017). Comparison of one step and step wise compression tests. Geologija. Geografija, 3(1), 1-10. https://doi.org/10.6001/geol-geogr.v3i1.3465

Skuodis, Š., Markauskas, D., Norkus, A., Žaržojus, G., \& Dirgèlienè, N. (2014). Testing and numerical simulation of Holocene marine sand uniaxial compression at Lithuanian coast. Baltica, 27(1), 33-44. https://doi.org/10.5200/baltica.2014.27.04

Suzuki, Y., Dyvik, R., \& Schmertmann, J. (2017). Experimental study on use of internal and external drains in triaxial tests. Geotechnical Testing Journal, 40(5), 810-821. https://doi.org/10.1520/GTJ20160266

Vangla, P., \& Latha, G. M. (2015). Influence of particle size on the friction and interfacial shear strength of sands of similar morphology. International Journal of Geosythetics and Ground Engineering, 1(6), 1-12. https://doi.org/10.1007/s40891-014-0008-9

Zhang, X., Baudet, B. A., Hu, W., \& Xu, Q. (2017). Characterisation of the ultimate particle size distribution of uniform and gapgraded soils. Soils and Foundations, 57(4), 603-618. https://doi.org/10.1016/j.sandf.2017.04.002 